be scrambling for hotel rooms in a city that has been fully booked for more than a year. But AIDS activists in the United States are doing everything they can to ease the accommodation problem by demanding a decrease in the size of the delegation from the US Department of Health and Human Services, which includes the National Institutes of Health and the Centers for Disease Control, among other agencies. In the short tradition of these conferences, a preconference row is par for the course, but this year's is sillier than most.

Armed with the information that the department plans to spend $\$ 1.5$ million of government funds to send 392 people to Florence, AIDS activists have enlisted the help of members of Congress in mounting a protest. They argue that the money could be better spent treating patients who are dying of the immunodeficiency disorder - subsidizing AZT for patients unable to pay, for instance. The department has answered that "everyone who is going has a worthwhile" reason. Really? Three hundred and ninety-two worthwhile reasons? Nobody would wish to deprive US researchers and health workers of a sight of the city that cradled the Renaissance, but the department's number is large enough to suggest that there could be a worthwhile conference if those concerned simply stayed at home. That is the cogent point the AIDS activists have grasped.

The protest goes off the rails by equating economies in the travel budget with the improved treatment of AIDS. The dollars saved even by cutting the official US delegation in half would make only a minor dent in the need for better care of AIDS patients. One is forced to the conclusion that the activists are not seeking to make a serious argument, but a debating-point. In doing so, they have overlooked the harm that would be done by a precedent that would have congressmen and activists dictating who attends a scientific meeting.

Those seeking to throw a spanner in the works should take a more direct line, starting from the plain truth that annual AIDS conferences have become unwieldly, unmanageable and unproductive. The original idea was that the world would hugely benefit from regular public reviews of the progress it was hoped researchers would make in tackling the public health problem by which the 1980 s will be remembered. But hope has not been matched by reality. Confident diagnosis is possible, there is a single drug that can be used to slow the progress of the disease and the management of patients has been much improved. But there is no cure or even sure prophylactic in sight.

That is the chief reason why only bad temper multiplies at these conferences. Researchers have a huge volume of new work to review each year, but there is not much to lift the hearts of the camp followers who scamper from one parallel session to another. So frustration abounds, driving the activists to protest that their interests are being neglected when the truth is that their constituents are the poignant victims of a problem of public health most obviously characterized by its obduracy. These are not the circumstances in which there can be a constructive assessment of what research has done. Serious researchers have been saying so for years, and many already save their most significant data for smaller conferen- ces, where the chances for real discussion are better.

The organizers should listen carefully, but urgently, to what they are saying. It is time to re-evaluate this carnival. And meanwhile, it is safe to predict that next year's preconference row will be a re-run of last year's. Last week, the US Department of Justice decided to override the opinion of the Department of Health and Human Services, which had taken the sensible view that infection with HIV should not be a reason for banning a person's entry to the United States. The Department of Justice is responding to public anxiety, not to the realities of what is known of the infection. Such obscurantism is also a bad precedent.

\section{Candidate for change}

The first Democratic candidate for US president would make technology his standard.

RECENT history has taught us not to expect much serious debate in the course of US presidential campaigns, which seem to have fallen victim to the 30 -second sound bites of the television age. So it is a welcome relief that the first man to throw his hat in the ring as a presidential candidate for the Democratic party in November 1992 plans to run on a platform grounded in science and technology.

Former US Senator Paul E. Tsongas of Massachusetts has written an 85-page campaign statement declaring that the future economic strength of the United States lies in the 'creation of national wealth' through a new manufacturing base and a strong commitment to research. In $A$ Call to Economic Arms, he says that the manufacturing base of the United States should be for the 1992 campaign, noting that Germany has 33 per cent of its workforce in manufacturing, Japan 28 per cent and the United States only 17 per cent, down from 26 per cent in 1970 . For a Democratic candidate, he also takes a radical stand when he declares that "corporate America must survive", if only on the grounds that a party committed to the redistribution of wealth "cannot redistribute wealth that is never created'.

Tsongas's solutions are two. First, he would bite the bullet on the issue of a national industrial policy, with the government making strategic investment decisions in areas including ceramic engines, supercomputers and memory chips. This is campaign rhetoric never heard before. Second, Tsongas would focus resources on the National Institutes of Health, the National Science Foundation, the National Aeronautics and Space Administration and the Departments of Energy and Agriculture, saying the United States should not be satisfied with marginal budget increases. He calls it a matter of 'mindset.' "The Manhattan Project. The Apollo program. The war in the Persian Gulf. It's just a matter of recognizing the threat and responding to it."

The significance of Paul Tsongas's platform is its seriousness. Here is a man trying his best to cast the presidential debate in terms of issues that really matter. He is on the right track. If he can elevate the debate, he will have performed an important service. He certainly deserves thanks for trying. $\square$ 